EVOLUȚIA SITUAȚIEI EPIDEMIOLOGICE PRIN HEPATITE CRONICE, CIROZE HEPATICE ȘI CANCER HEPATIC ÎN REPUBLICA MOLDOVA

\author{
Angela PARASCHIV \\ Universitatea de Stat de Medicină și Farmacie „Nicolae Testemițanu”, Republica Moldova
}

Autor corespondent: Angela Paraschiv, e-mail: angela.paraschiv@usmf.md_

DOI: 10/38045/ohrm.2021.2.11

CZU: [616.36-002.2+616.36-004+616.36-006]-036.22(478)

Keywords: chronic hepatitis, liver cirrhosis, primary liver cancer, prevalence, morbidity, risk factors.

Cuvinte cheie: hepatită cronică, ciroză hepatică, cancer hepatic primar.

\section{EPIDEMIOLOGICAL EVOLUTION OF CHRONIC HEPATITIS, LIVER CIRRHOSIS AND LIVER CANCER IN THE REPUBLIC OF MOLDOVA}

Introduction. The burden of liver diseases is a major health issue, being underestimated both at national and international level. In the Republic of Moldova, there are over 70 thousand patients with chronic hepatitis and over 10 thousand people suffering from liver cirrhosis. 70\% of patients with cirrhosis develop liver cancer. Over 2,000 patients die annually from complications caused by liver cirrhosis, and over 400 patients die due to primary liver cancer.

Material and methods. The statistical analysis of 2000-2019 reports, presented by Agency for Public Health, as well as of 3666 patient medical records retrieved from "Timofei Mosneaga" Republican Hospital, „Toma Ciorba” Clinical Hospital and "Sfinta Treime” Clinical Hopital was carried out.

Results. 89290 cases of chronic hepatitis, liver cirrhosis and liver cancer have been officially registered. Most of them exhibited a viral etiology. The death rate was mostly recorded in patients aged 70-79. The mean age of patients with chronic hepatitis was $57.74 \pm 11.22$, liver cirrhosis - 56.21 \pm 10.17 , and liver cancer-59.05 \pm 10.94 . The risk factors included unprotected sex, use of sharp objects, scissors and syringes, noncompliance with dietary regimens, alcohol and tobacco use, etc. Close relatives were also investigated for the presence of viral markers in only $38.81 \%$ cases of chronic hepatitis and in $24.37 \%$ patients with liver cirrhosis

Conclusions. The study of common epidemiological evolution of chronic hepatitis, liver cirrhosis and primary liver cancer in population, while considering the patient's close relationship, might reduce both morbidity and medical and socio-economic impact.

Introducere. Povara patologilor ficatului reprezintă o problemă majoră și, cu siguranță, este subestimată atât la nivel național, cât și la nivel global. În Republica Moldova sunt înregistrați peste 70 de mii pacienți cu hepatită cronică și peste 10 mii - cu ciroză hepatică, iar cca 70\% dintre pacienții cu ciroză dezvoltă cancer hepatic. Anual, circa 2 mii de bolnavi decedează în urma complicațiilor cauzate de ciroză hepatică, iar peste 400 de bolnavi - ca urmare a cancerului hepatic primar.

Material și metode. Au fost analizate rapoartele statistice pentru anii 2000-2019, prezentate de Agenția Națională pentru Sănătate Publică și 3666 fișe de observație ale pacienților internați în SCR „Timofei Moșneaga”, SC Boli infecțioase „Toma Ciorbă” și SCM "Sfânta Treime”, pentru perioada 2015-2019.

Rezultate. Oficial sunt înregistrate 89290 de cazuri de hepatite cronice, ciroze hepatice și de cancer hepatic, majoritatea fiind de etiologie virală. Decesele sunt înregistrate preponderent la vârsta de 70-79 de ani. Vârsta medie a pacienților cu hepatite cronice este de $57,74 \pm 11,22$, cu ciroze hepatice - 56,21 $\pm 10,17$ și a celor cu cancer hepatic 59,05 $\pm 10,94$. Factorii de risc frecvenți sunt relațiile sexuale neprotejate, utilizarea obiectelor ascuțite în comun, a foarfecelor și a seringilor nesterile, nerespectarea regimului alimentar, consumul de alcool și de tutun etc. Membrii familiei au fost investigați la prezența markerilor virali doar în 38,81\% de cazuri cu hepatite cronice și 24,37\% pentru cei cu ciroze hepatice.

Concluzii. Studierea particularităților epidemiologice a hepatitelor cronice, a cirozelor hepatice și a cancerului hepatic primar în rândul populației, ținând cont de legătura strânsă dintre ele, va permite reducerea atât a morbidității, cât și a impactului medical și a celui socio-economic. 


\section{INTRODUCERE}

În ultimele decenii s-a atestă o creștere constantă a incidenței patologiei hepatice, care este o problemă gravă a medicinei moderne și, este cu siguranță subestimată atât la nivel național, cât și la nivel global (1 - 4). Estimările actuale la nivel mondial arată că 844 de milioane de persoane suferă de boli hepatice cronice, cu o rată a mortalității de 2 milioane de decese pe an, inclusiv 1 milion de decese din cauza complicațiilor de ciroză și 1 milion ca urmare a hepatitei virale și a carcinomului hepatocelular $(5,6,7)$. Acestea pot $\mathrm{fi}$ comparate și cu alte probleme grave de sănătate publică, asociate bolilor cronice, precum diabetul - 422 dee milioane de cazuri și 1,6 milioane decese, bolile pulmonare - 650 de milioane de cazuri, 6,17 milioane decese și bolile cardiovasculare - 540 de milioane de cazuri, 17,7 milioane decese (8 - 11).

Astfel, la această etapă hepatita cronică, ciroza hepatică și cancerul hepatic primar reprezintă una dintre cele mai grave probleme pentru omenire, datorită răspândirii globale, morbidității și a mortalității crescute, precum și a gradului ridicat de dizabilitate, cauzat de evoluția rapidă a acestor patologii. La nivel global, aproximativ $257 \mathrm{de} \mathrm{mi-}$ lioane de persoane sunt infectate cu hepatită cronică $\mathrm{B}$, iar alte 71 de milioane cu hepatită cronică virală $C$, în special în țările cu venituri mici și medii.

În Republica Moldova, în 2019, s-au înregistrat peste 70 de mii de pacienți cu hepatită cronică și peste 10 mii cu ciroză hepatică, iar 70\%, dintre pacienții cu ciroză au dezvoltat cancer hepatic primar.

Ipoteza studiului: Studiul în cauză vizează una dintre problemele majore în domeniul Sănătății Publice. Actualmente problema hepatitelor cronice, cirozelor hepatice și a cancerului hepatic nu a fost studiată în comun. Astfel, ne-am propus abordarea acestor patologii în complexitate, pentru a evidenția particularitățile bolilor în cauză, în diferite etape de dezvoltare și evidențierea unor factori de risc, ce determină cronicizarea pacienților, prin dezvoltarea cirozelor hepatice și a cancerului hepatic primar.

\section{MATERIAL ȘI METODE}

Materialul primar utilizat, pentru realizarea studiului, a fost colectat din datele statistice fur- nizate de Agenția Națională de Sănătate Publică, documentate în Forma nr. 2, Raportul privind unele boli infecțioase și parazitare înregistrate în Republica Moldova (pentru analiza morbidității prin hepatite acute) și Darea de seamă nr. 29 privind bolnavii cu hepatite cronice și ciroze hepatice. Acest studiu este unul epidemiologic retrospectiv al morbidității prin hepatitei cronice, ciroze hepatice și a cancerului hepatic primar. Totodată, fost analizată și mortalitatea cauzată de aceste boli în ansamblu, în Republicii Moldova. Pentru a evidenția factorii de risc, care contribuie la evoluția cronică a hepatitelor și dezvoltarea ulterioară a cirozei și a cancerului hepatic primar, au fost chestionați 3666 de pacienți, inclusiv cu hepatită cronică - 1528 de persoane, cu ciroză hepatică - 1891 de persoane și cu cancer hepatic primar - 247 de pacienți. Pentru determinarea factorilor de risc a fost realizat un studiu de caz și de control, pentru a evidenția probabilitatea riscului (OR) pentru fiecare factor analizat. Grupul principal a fost constituit din pacienți care suferă de aceste boli, iar grupul de control de persoane care au bolile în cauză. Pacienții au fost divizați în 3 grupuri de studiu. În primul grup au intrat pacienții cu hepatită cronică și un grup de control (persoane sănătoase), în grupul II - pacienți cu ciroză hepatică și un grup de control (pacienți cu hepatită cronică), în grupul III - pacienți cu cancer hepatic primar și un grup de control (pacienți cu ciroză hepatică). OR a fost calculată în baza formulei: cotele unui eveniment din grupul expus/ cotele unui eveniment din grupul neexpus. Dacă raportul de cote este mai mare de 1 , rezultă că probabilitatea ca evenimentul să aibă loc în grupul expus, este mai mare decât în grupul neexpus. Rezultatele au fost procesate utilizând Programul Epi Info 7.2.

\section{REZULTATE}

Analiza situației epidemiologice în Republica Moldova, privind morbiditatea prin hepatite cronice, ciroze hepatice și cancer hepatic, denotă o creșterea evidentă a cazurilor în toată perioada analizată, anii 2000-2019. În special, în anul 2019 au fost înregistrate în total 89290 de cazuri de hepatite cronice, ciroze hepatice și de cancer hepatic primar, dintre care 78643 de pacienți cu hepatite cronice, 10246 - cu ciroze hepatice și 401 -cu cancer hepatic. Dinamica multianuală a morbidității, prin hepatite cronice, s-a mărit de 2 ori în perioa- 
da de studiu, de la 1092,2 $\pm 5,68$ cazuri la $100 \mathrm{mii}$ de locuitori (46667 de cazuri) în anul 2000, până la 2218,34 7,83 cazuri la 100 mii de locuitori în 2019. Morbiditatea prin ciroze hepatice a progresa de la 168,6 $\pm 2,23$ cazuri la 100 mii de locuitori în 2000, până la 289,02 $\pm 2,89$ cazuri la 100 mii de locuitori în 2019, iar morbiditatea prin cancer hepatic a sporit de la $5,1 \pm 0,37$ cazuri la 100 mii de locuitori, până la 12,01 $\pm 0,59$ cazuri la 100 mii de locuitori în 2019 (fig.1).

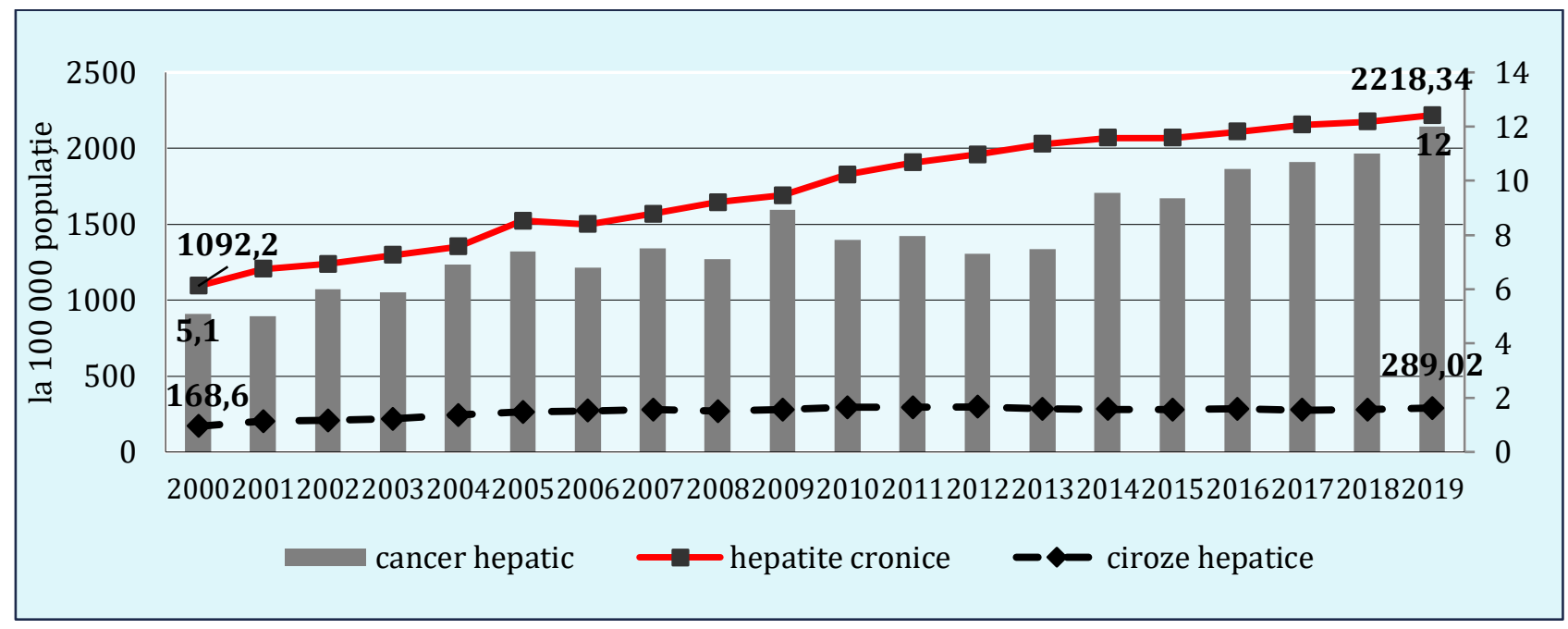

Figura 1. Dinamica multianuală a morbidității prin hepatite cronice, ciroze hepatice și cancer hepatic în Republica Moldova, perioada 2000-2019.

Analiza retrospectivă a morbidității, prin hepatite cronice, demonstrează faptul că, dacă la începutul perioadei analizate predominau cazurile de etiologie nevirală în $63,67 \pm 0,27 \%$ de cazuri, comparativ cu cele de etiologie virală $-36,33 \pm 0,36 \%$ de cazuri, atunci în 2019 situația s-a schimbat considerabil (fig.2). Astfel, la etapa actuală majoritatea cazurilor sunt determinate de hepatitele cronice virale în $64,25 \pm 0,21 \%$ de cazuri, comparativ

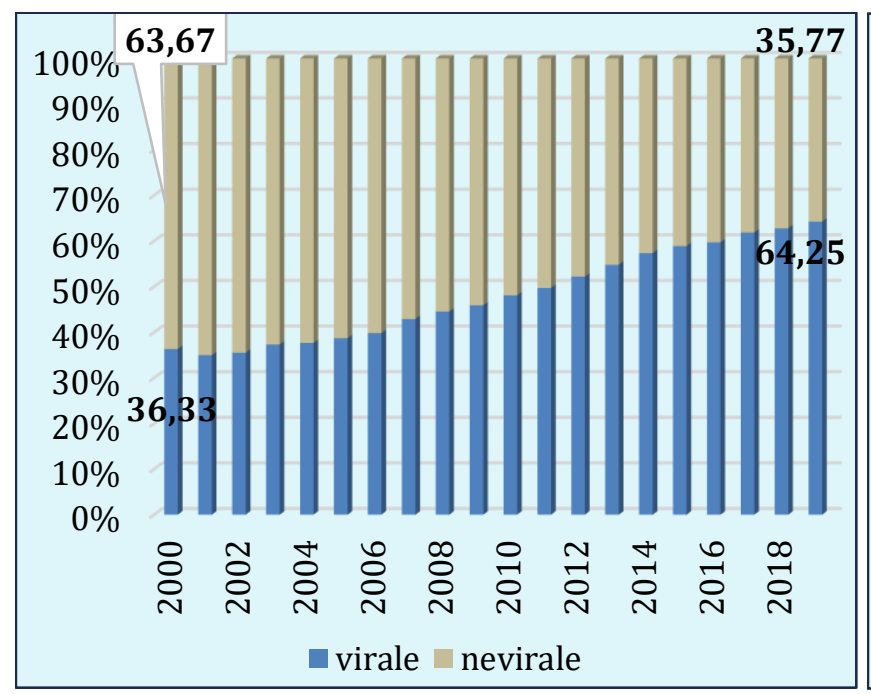

Figura 2. Ponderea hepatitelor cronice virale și nevirale, în Republica Moldova, în dinamica multianuală, perioada 2000-2019. cu cele de etiologie nevirală - 35,77 $\pm 0,28 \%$ de cazuri. 0 situație similară s-a înregistrat și în cazul cirozelor hepatice, dacă la începutul perioadei analizate (anul 2000), cirozele hepatice de etiologie nevirală au constituit $77,94 \%$ de cazuri, comparativ cu cele virale $-22,06 \%$, atunci în anul 2019 ponderea acestora a progresat până la $53,5 \%$, iar cele nevirale s-au redus până la 46,49\% (fig.3).

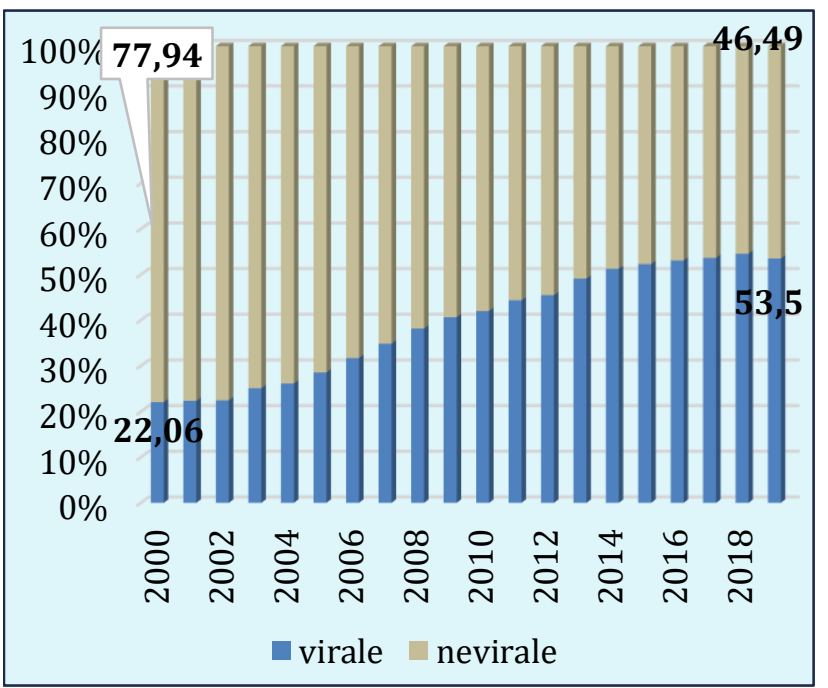

Figura 3. Structura etiologică a cirozelor hepatice de origine virală şi neviral, în Republica Moldova, în dinamica multianuală, perioada 2000-2019. 
Numărul de pacienți cu hepatită cronică virală a crescut practic de 3 ori, de la 16955 de cazuri în anul 2000, până 50525 de cazuri în 2019. La majoritatea pacienților s-a izolat virusul hepatitei B. În dinamica multianuală indicii de prevalență a morbidității prin HVB cronică s-au majorat de la 8817 cazuri $(206,4$ cazuri la 100 mii de locuitori) în 2000, până la 30264 de cazuri $(853,68$ de cazuri la 100 mii de locuitori) în 2019 (fig.4).

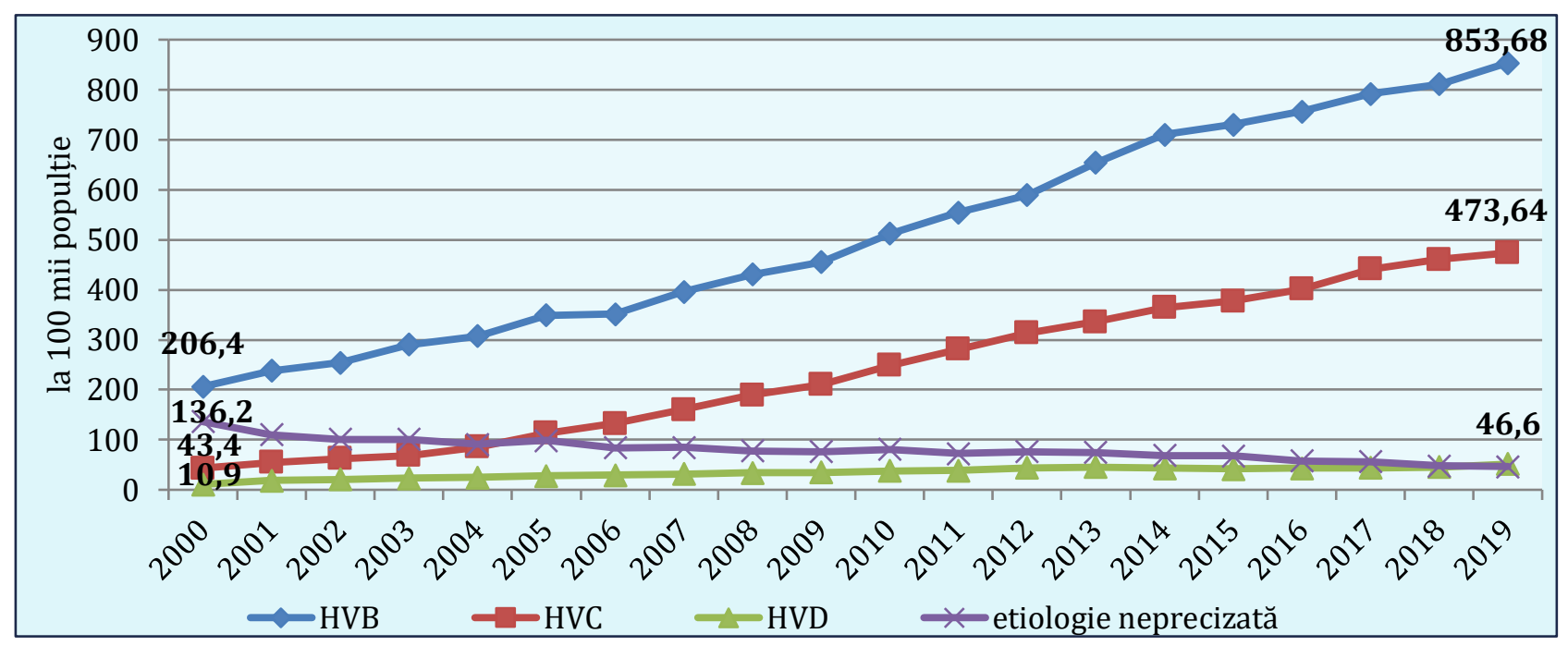

Figura 4. Dinamica multianuală a morbidității prin hepatite virale cronice provocate de virusurile „B”, , „C”, „D” şi de etiologie neprecizată.

Este alarmantă situația în cazul hepatitelor cronice cauzate de virusul $C$, unde prevalența pacienților a crescut practic de 9 ori în perioada analizată, de la 1855 de cazuri $(43,4$ de cazuri la 100 mii de locuitori) în 2000, până la 16791 de cazuri (473,64 de cazuri la 100 mii de locuitori) în 2019. Morbiditatea prin hepatite virale cronice cauzate de virusul D s-a majorat de la 464 de cazuri $(10,9$ cazuri la 100 mii de locuitori) în 2000, până la 1818 cazuri (51,28 de cazuri la 100 mii de locuitori) în 2019. Totodată, se înregistrează o diminuare substanțială a cazurilor de hepatite cronice virale, de altă etiologie și neprecizate, de la 5819 cazuri (136,2 de cazuri la 100 mii de locuitori) în 2000, până la 1652 de cazuri $(46,60$ de cazuri la 100 mii de locuitori) în 2019.

Situația epidemiologică, privind cirozele hepatice de etiologie virală, denotă o creștere a morbidității de 3 ori în 2019, față de primul an analizat2000. Astfel, numărul de pacienți cu ciroze hepatice de etiologie virală a sporit de la 1589 de cazuri în 2000, până la 5482 de cazuri în 2019. La fel ca în cazul hepatitelor cronice virale, majoritatea pacienților au fost depistați cu virusul hepatitei B.

În dinamica multianuală indicii de prevalență a morbidității prin CHB s-au amplificat de la 655 de cazuri (15,3 cazuri la 100 mii de locuitori) în 2000, până la 2422 de cazuri $(68,32$ de cazuri la 100 mii de locuitori) în 2019 (fig.5).

Indicii de prevalență în ciroze hepatice cauzate de virusul C, a sporit practic de 9 ori, de la 229 de cazuri (5,4 cazuri la 100 mii de locuitori) în 2000, până la 2240 de cazuri $(63,19$ cazuri la 100 mii de locuitori) în 2019. Morbiditatea prin ciroze hepatice virale, cauzate de virusul D, s-a majorat de la 183 de cazuri (4,3 cazuri la 100 mii de locuitori) în 2000, până la 400 de cazuri $(11,28$ cazuri la 100 mii de locuitori) în 2019. Cirozele hepatice virale, de altă etiologie și cele neprecizate, au înregistrat o diminuare ușoară de la 522 de cazuri $(12,2$ cazuri la 100 mii de locuitori) în 2000, până la 420 de cazuri $(11,85$ de cazuri la 100 mii de locuitori) în 2019.

Analiza situației epidemiologice în Republica Moldova pentru ultimii 11 ani (2009-2019) demonstrează că majoritatea pacienților înregistrați, cu patologiile analizate în acest studiu, decedează în faza de ciroză hepatică, iar unii - în faza de cancer hepatic.

Totodată, este de menționat faptul că în aceeași perioadă (2009-2019) mortalitatea, din cauza hepatitelor cronice și a cirozelor hepatice, este în scădere. Așadar, dacă în 2009 erau înregistrate 31 
de cazuri $(0,84$ cazuri la $100 \mathrm{mii}$ de locuitori) de decese, ca rezultat al hepatitelor cronice, atunci în 2019 numărul persoanelor, care au decedat de această patologie, s-a redus practic de 2 ori, constituind 15 cazuri $(0,4$ cazuri la 100 mii de locuitori) (fig. 6). Decesele cauzate de ciroze hepatice s-au redus de la 3117 cazuri $(87,42$ de cazuri la
100 mii de locuitori) în 2000, până la 2367 de cazuri $(66,77$ de cazuri la 100 mii de locuitori) în 2019. Numărul de decese cauzate de cancer hepatic s-a dovedit a fi stabil, pe toată perioada analizată, variind de la 424 de cazuri $(11,89$ cazuri la 100 mii de locuitori) în 2000 și 447 de cazuri (12,6 cazuri la 100 mii de locuitori) în 2019.

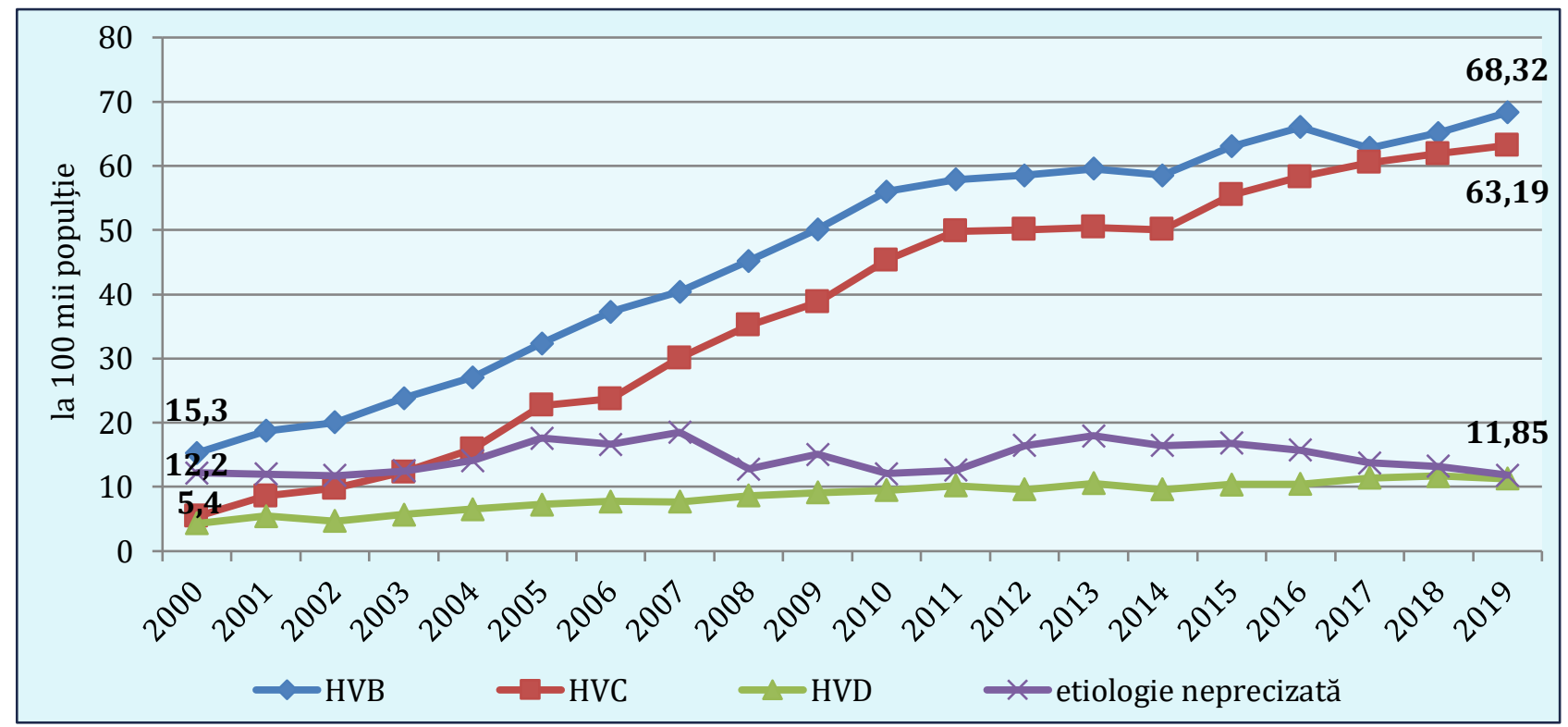

Figura 5. Dinamica multianuală a morbidității prin ciroze hepatice provocate de virusurile „B”, „C", „D” şi de etiologie neprecizată.

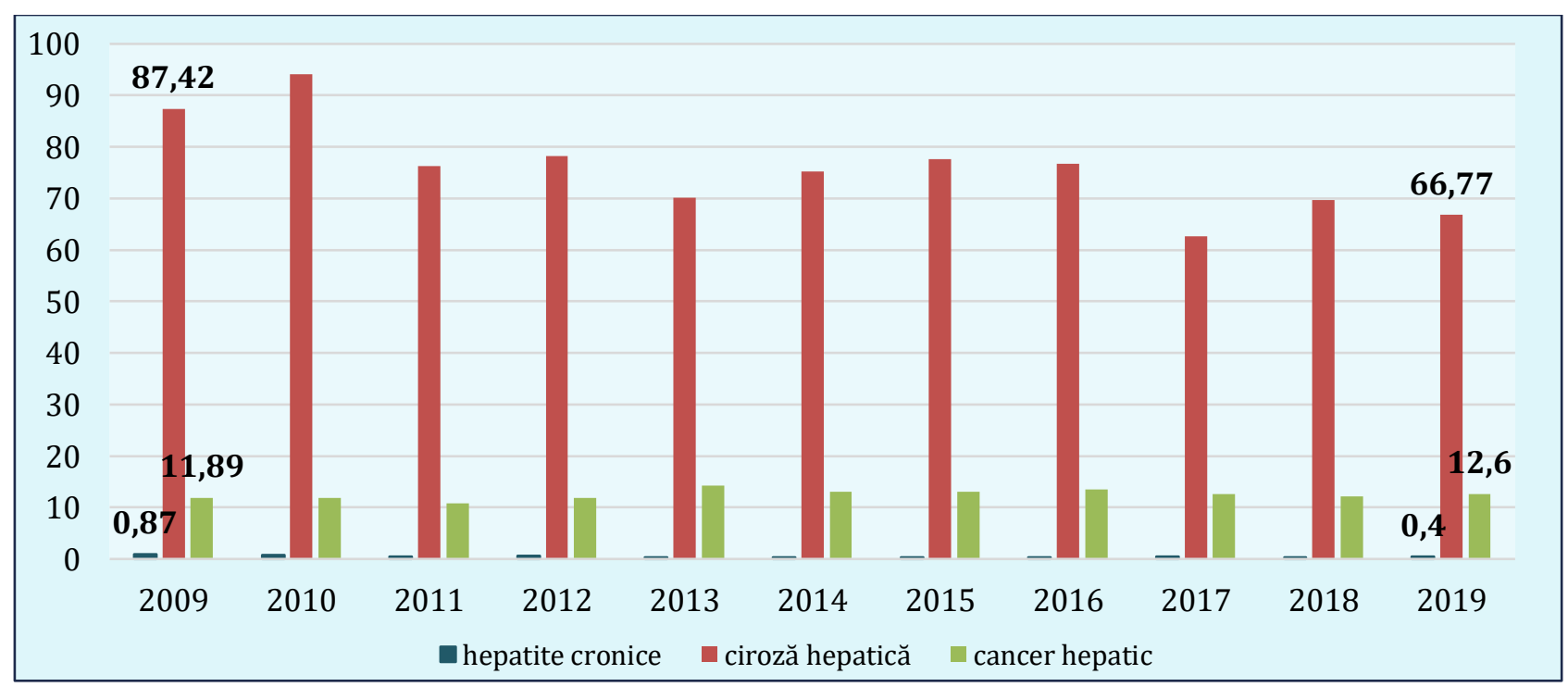

Figura 6. Dinamica multianuală a mortalității prin hepatite cronice, ciroze hepatice și cancer hepatic în Republica Moldova, în perioada 2009-2019 (la 100 mii de locuitori).

Cazuri de deces au fost înregistrate practic la toate categoriile de vârstă, inclusiv la copii de $0-4$ ani. În majoritatea situațiilor, decesele sunt înregistrate la pacienții cu vârsta de 70-79 ani, atât la cei cu ciroze hepatice, cât și la cei cu cancer hepatic $(2,72$ cazuri si respectiv 0,63 cazuri la 1000 de locuitori) (fig.7, 8).

Numărul cazurilor de decese, printre pacienții cu ciroze hepatice și cancer hepatic, se amplifică odată cu înaintarea în vârstă (fig.7, 8). 


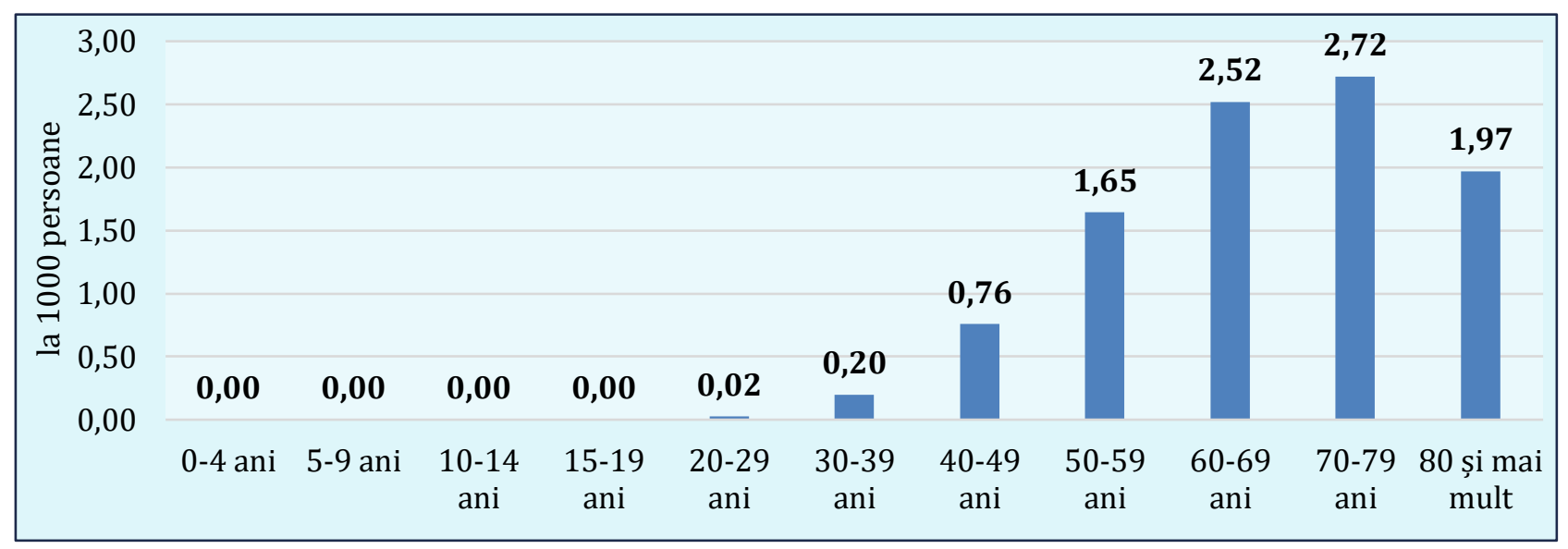

Figura 7. Indicii medii ai mortalității prin ciroze hepatice, în funcție de vârstă, în Republica Moldova, pentru anii 2009-2019 (la 1000 de locuitori).

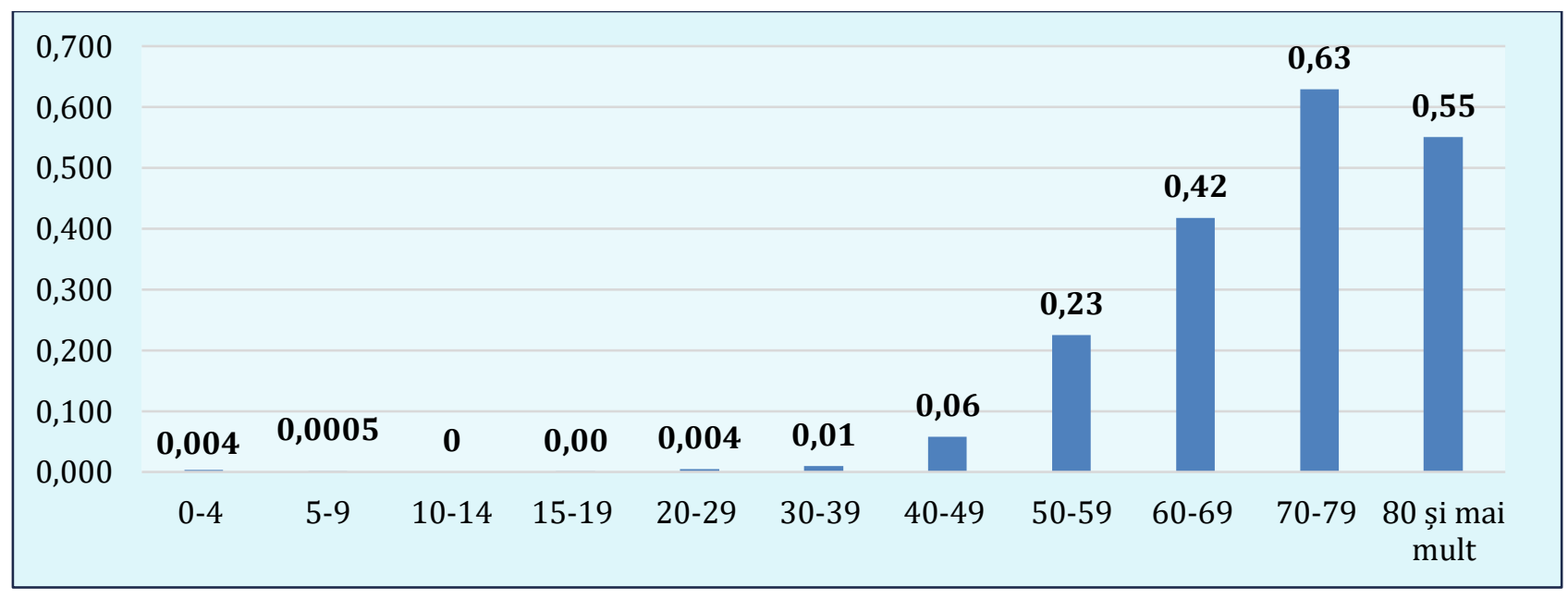

Figura 8. Indicii medii ai mortalității prin cancer hepatic, în funcție de vârstă, în Republica Moldova, pentru anii 2009-2019 (la 1000 de locuitori).

Evoluția hepatitelor cronice în ciroze hepatice și în cancer hepatic primar este condiționată de un șir de particularități epidemiologice și de factori de risc, asociați diagnosticului de bază. În acest context, au fost analizate fișele de observație a 3666 de pacienți, inclusiv cu hepatite cronice 1528 de bolnavi $(41,68 \pm 1,26 \%)$, cu ciroze hepatice 1891 de bolnavi $(51,58 \pm 1,14 \%)$ și cu cancer hepatic - 247 de bolnavi $(6,74 \pm 1,59 \%)$, pentru a stabili factorii de risc care contribuie la evoluția hepatitelor cronice în ciroze hepatice și în cancer hepatic primar. Analiza patologiilor hepatice cronice denotă că, mai frecvent hepatite cronice se înregistrează la femei, însă evoluția acestora în ciroze hepatice și în cancer hepatic se evidențiază, mai frecvent, printre bărbați. Astfel, hepatitele cronice la femei au fost înregistrate în 873 de cazuri sau 57,13 $\pm 1,67 \%$ [95\%, CL:54,64-59,59],

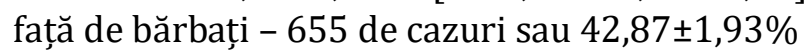

[95\%, CL;40,41-45,36] $(\mathrm{P}<0,001) . \quad$ Raportul dintre bărbați și femei a constituit 1,33 (873:655),

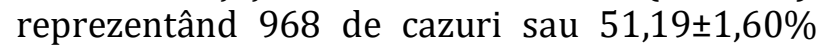
[95\%, CL;48,94-53,44] și respectiv 923 de cazuri sau $48,81 \pm 1,64 \%$ [95\%, CL;46,56-51,06]. 0 pondere mai mare a bărbaților afectați s-a dovedit a fi printre pacienții cu cancer hepatic primar. Bărbații, cu cancer hepatic primar, au constituit 156 de cazuri sau $63,16 \pm 3,86 \%$ [95\%, CL;56,8169,19], față de femei - 91 de cazuri sau 36,84 $\pm 5,05 \%$ [95\%, CL;30,81-43,19] (fig.9).

Vârsta medie a pacienților cu hepatite cronice a constituit 57,74 $\pm 11,22$, cu ciroze hepatice de $56,21 \pm 10,17$ și cu cancer hepatic de 59,05 $\pm 10,94$ (fig.10).

Totodată, este de menționat faptul că, hepatitele cronice, cirozele hepatice și cancerul hepatic au fost înregistrate și la copii cu vârsta de 10 ani. Majoritatea cazurilor de hepatite cronice și ciroze 
hepatice au fost înregistrate la pacienții cu vârsta de $50-59$ de ani (37,50\% și 39,56\% respectiv), iar în cazul cancerului hepatic - în grupa de vârstă de 60-69 de ani (49,80\%) (fig.11).

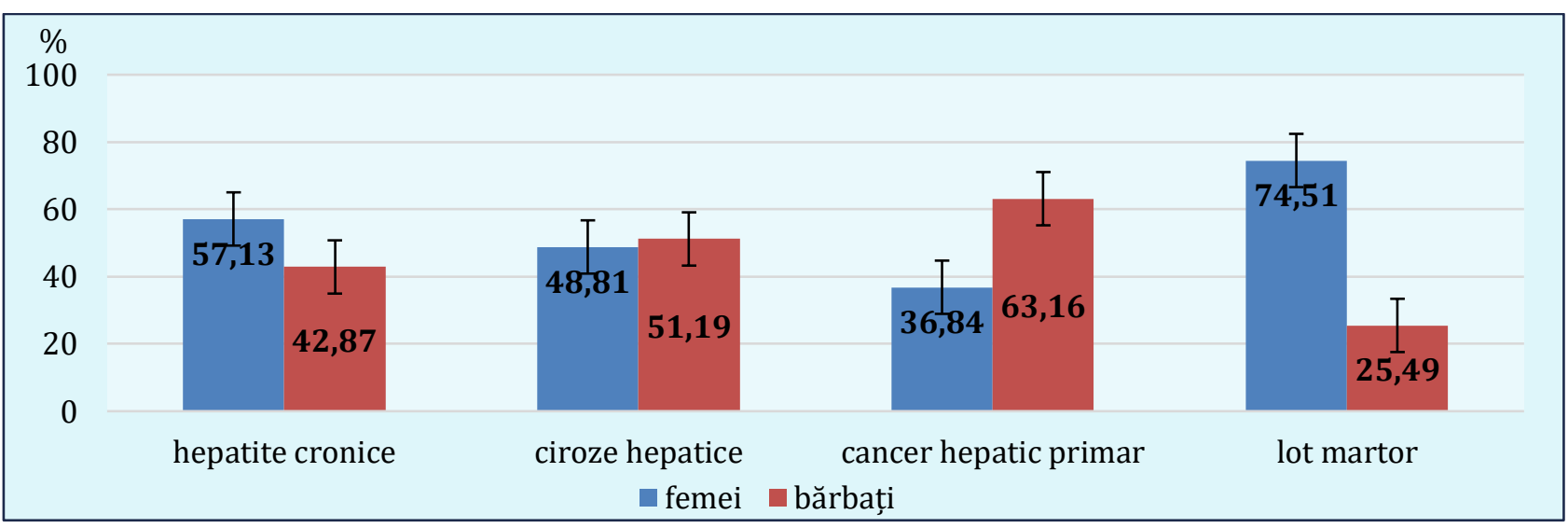

Figura 9. Structura patologiei ficatului în funcție sex.

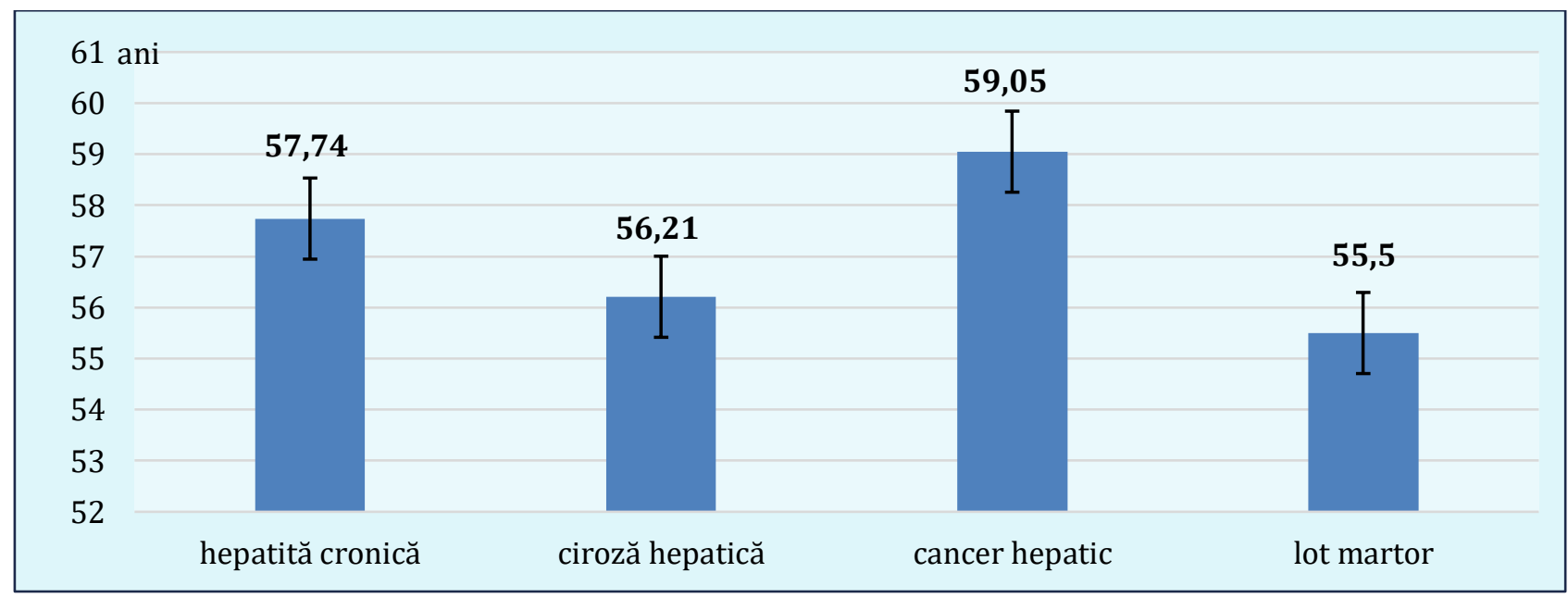

Figura 10. Ponderea pacienților în funcție de vârsta medie.

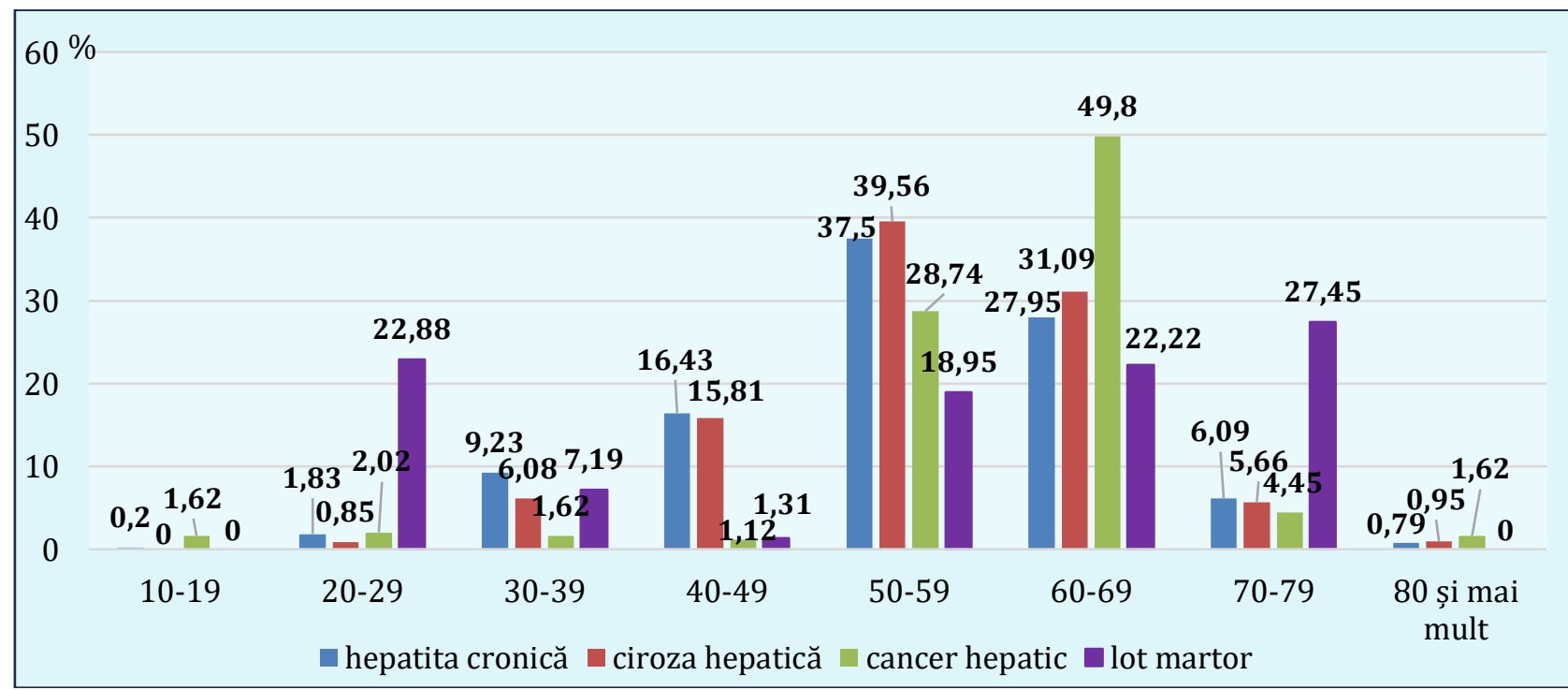

Figura 11. Ponderea patologiilor hepatice în funcție de grupele de vârstă. 
Pacienții cu hepatite cronice, ciroze hepatice și cancer hepatic au fost chestionați pentru a determina factorii de risc comportamentali, după care au fost analizați în programul EpiInfo 7.2. Analiza factorilor de risc, prin metoda regresiei liniare, a constatat că, pentru pacienții cu hepatite cronice OR înalt a fost în cazul pacienților care practică relații sexuale neprotejate - 1378 de pacienți (OR=5,92; 95\%: $\mathrm{Cl} 4,11-8,54, \mathrm{P}<0,001)$, utilizarea obiectelor ascuțite în comun - 925 de pacienți $(\mathrm{OR}=1,91$; 95\%: $\mathrm{Cl}$ 1,3-2,68, $\mathrm{P}<0,001)$, utilizarea în comun a foarfecii - 845 de pacienți $(O R=1,15$; 95\%: $\mathrm{Cl} 0,83-1,61, \mathrm{P}=0,38$ ) și utilizarea în comun a seringilor -37 de pacienți $(\mathrm{OR}=1,24 ; 95 \%$ : $\mathrm{Cl}$ 0,37-4,07, P=0,38) (fig.12).

Pentru pacienții cu ciroze hepatice, OR înalt a fost în cazul relațiilor sexuale neprotejate - 1831 de pacienți $\quad(\mathrm{OR}=19,68 ;$ 95\%: $\mathrm{Cl}$ 13,01-29,78, $\mathrm{P}<0,001$ ), utilizarea obiectelor ascuțite în comun - 1358 de pacienți $(\mathrm{OR}=3,15$; 95\%: $\mathrm{Cl} 2,25-4,4$, $\mathrm{P}<0,001)$ și utilizarea în comun a lamei de bărbierit -100 de pacienți $(\mathrm{OR}=1,36$; 95\%: $\mathrm{Cl}$ 0,59-3,17, $\mathrm{P}=0,46)$.

Pentru pacienții cu cancer hepatic, OR înalt a fost în cazul utilizării obiectelor ascuțite în comun 239 de pacienți $(\mathrm{OR}=37,34$; 95\%: $\mathrm{Cl}$ 17,23-80,91 $\mathrm{P}<0,001$ ), a relațiilor sexuale neprotejate $-241 \mathrm{de}$ pacienți (OR=25,91; 95\%: $\mathrm{Cl}$ 10,82-62,01, $\mathrm{P}<0,001)$, utilizarea în comun a periuței de dinți 31 de pacienți (OR=5,34; 95\%: $\mathrm{Cl}$ 1,84-15,46, $\mathrm{P}<0,001)$ și utilizarea în comun a foarfecii -154 de pacienţi (OR=1,55; 95\%: $\mathrm{Cl}$ 1,03-2,33, $\mathrm{P}=0,003$ ).

Totodată, pacienții cu patologiile ficatului au fost chestionați privind respectarea regimului alimentar și a consumului de alcool și tutun. Astfel, analiza datelor, prin metoda regresie liniare, a demonstrat că în cazul pacienților cu hepatite cronice, factorul de risc cu $\mathrm{OR}>1 \mathrm{~s}$-a dovedit a fi nerespectarea regimului alimentar prescris de medicul specialist și de consumul de alcool.

În cazul consumului cronic al unei cantități excesive de alcool, sporește riscul progresiei, cu dezvoltarea mai rapidă a fibrozei și a cirozei hepatice $(6,14,15)$.

Din cei 1528 de pacienți cu hepatite cronice, nerespectarea regimului alimentar au menționat 835 de pacienți - 54,65\% (OR=1,43; 95\%: Cl 1,01$2,02, \mathrm{P}=0,01$ ), iar problema consumului de alcool au menționat 605 pacienți $-39,59 \%$ (OR=1,01;
95\%: $\mathrm{Cl} 0,72-1,42, \mathrm{P}=0,46)$.

Analiza datelor prin regresie liniară, pentru pacienții cu ciroze hepatice, a evidențiat în calitate de factor de risc doar consumul de alcool, care a fost menționat de 723 de pacienți - 38,23\% (OR=3,06; 95\%: Cl:2,57-3,64, P=0,00001). Pentru pacienții cu cancer hepatic, factorii de risc s-au dovedit a fi nerespectarea regimului alimentar și consumul de alcool. Nerespectarea regimului alimentar au menționat - 213 pacienți - 86,23\% (OR=1,29; 95\%: $\mathrm{Cl}: 0,87-1,91, \mathrm{P}=0,09)$, iar consumul de alcool a fost menționat de 164 de pacienți - 66,40\% (OR=3,19; $95 \%$ Cl: 2,41-4,22, $\mathrm{P}=0,00001)$.

Peste 90\% dintre pacienții cu hepatite cronice și ciroze hepatice s-au aflat în staționar, pentru tratament, doar 10 zile. Pe parcursul aflării în staționar majoritatea au primit tratament simptomatic (hepatite cronice - 45,45\%, iar în cazul cirozelor hepatice - 54,47\%) și doar în $24,68 \%$ de cazuri pacienții cu hepatite cronice au primit tratament antiviral, iar cei cu ciroze hepatice $-21,95 \%$.

Membrii familiei pacienților, depistați cu hepatite cronice sau ciroze hepatice, au fost investigați la markeri virali doar în 38,81\% și, respectiv $24,37 \%$ de cazuri.

Totodată, este de menționat și faptul că membrii familiei pacienților cu hepatită virală cronică B au fost vaccinați doar în proporție de 18,46\%, iar cu ciroze hepatice și mai puțin - 15,25\%. În 81,54 de cazuri respondenții au menționat că, membrii familiei nu au primit vaccin contra hepatitei virale B.

Pacienții cu hepatite cronice și cu ciroze hepatice au evidențiat prezența condițiilor nocive de muncă (fig.12) cum ar fi îngrășăminte (18,42\% și $15,15 \%$ respectiv), activități la ferma de animale $(15,79 \%$ și $14,14 \%$ respectiv), insecticide (14,47\% și $14,14 \%$ respectiv), pesticide $(11,84 \%$ și 13,13\%), detergenți chimici $(11,84 \%$ și $13,13 \%)$, etc.

\section{DISCUȚII}

Controlul eficient al bolilor transmisibile se bazează pe eficiența sistemului de supraveghere epidemiologică. Un sistem de supraveghere funcțional la nivel național este bazat pe realizarea acțiunilor de prevenire și de control, al bolilor transmisibile prioritare. Obiectivele supravegherii epidemiologice constau în stabilirea particula 


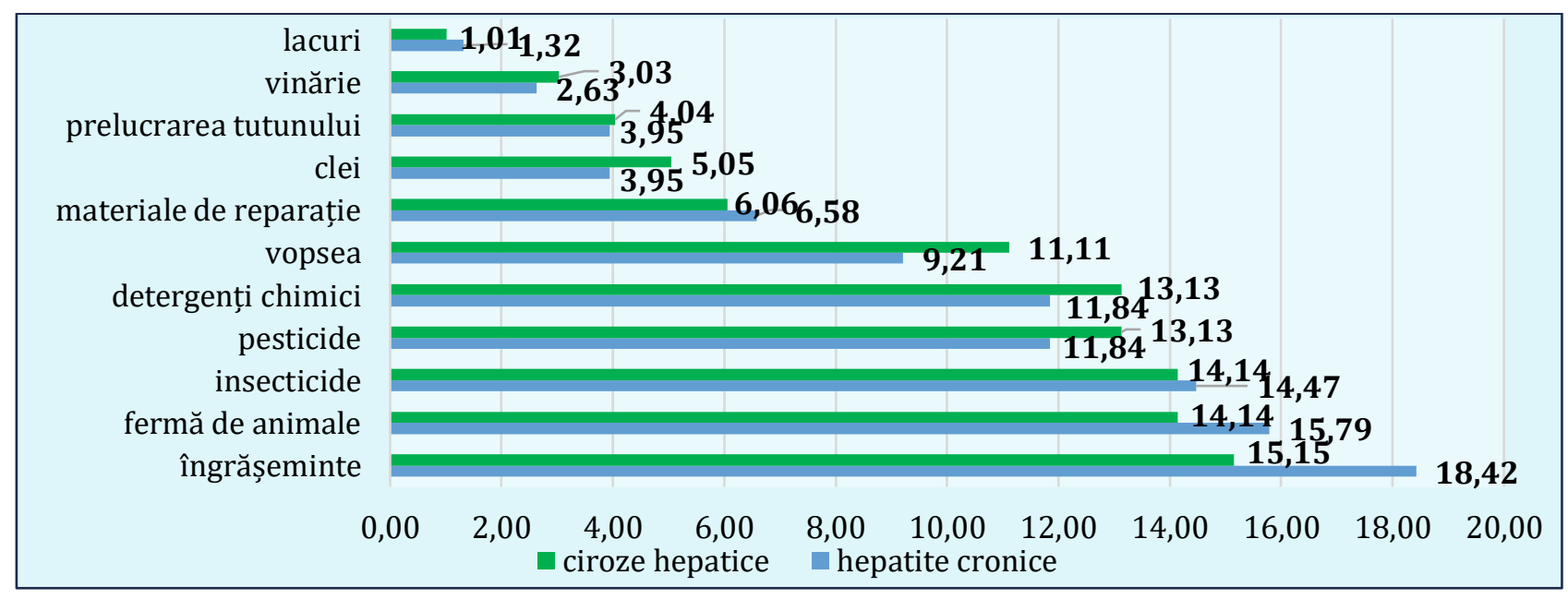

Figura 12. Ponderea pacienților cu hepatite cronice și ciroze hepatice în funcție de condițiile nocive de muncă.

rităților și a evoluției procesului epidemic, în funcție de componentele de bază (timp, loc, persoană); stabilirea cauzelor și a condițiilor apariției cazurilor de boală, depistarea izbucnirilor epidemice și prognozarea evoluției lor; monitorizarea realizării programelor naționale de control al maladiilor; evaluarea eficacității măsurilor de prevenire și de control. Analiza situației epidemiologice în Republica Moldova privind hepatitele cronice, cirozele hepatice și cancerul hepatic a evidențiat că, indicii morbidității sunt în continuă creștere, iar situația necesită o soluționare urgentă. Este evident faptul că, studierea particularităților de manifestare epidemiologică a hepatite-lor cronice, a cirozelor hepatice și a cancerului hepatic, în complexitate, va permite aplicarea măsu-rilor de prevenire și de control eficiente, la diferite niveluri de asistență medicală, inclusiv etapa de îngrijire prespitalicească și cea spitalicească a pacientului. Monitorizarea indicilor de evoluție și de agravare a stării de sănătate a pacientului va permite implicarea precoce a specialistului, pen-tru prevenirea evoluției hepatitei cronice în ciro-ză hepatică și, ulterior, în cancer hepatic primar.

\section{CONCLUZII}

Astfel, din cele menționate, se constată că problema hepatitelor cronice, a cirozelor hepatice și cea a cancerului hepatic primar este deosebit de stringentă la etapa actuală, care necesită soluționare. Analiza situației epidemiologice privind hepatitele cronice, cirozele hepatice și cancerul hepatic au evidențiat următoarele:

1. Indicii de prevalență a morbidității prin hepatite cronice, ciroze hepatice și prin cancer hepatic este în continuă creștere.

2. Majoritatea hepatitelor cronice și a cirozelor hepatice sunt de etiologie virală.

3. Numărul pacienților cu HVB cronică s-a majorat de la 8817 de cazuri în 2000, până la 30264 de cazuri în 2019, iar în cazul hepatitelor cronice provocate de virusul C, s-a amplificat practic de 9 ori, de la 1855 de cazuri în 2000, până la 16791 de cazuri în 2019.

4. Numărul pacienților cu ciroză hepatică B a sporit de la 655 de cazuri în 2000, până la 2422 de cazuri în 2019, iar cu ciroze hepatice cauzate de virusul C, a sporit practic de 9 ori, de la 229 de cazuri în 2000, până la 2240 de cazuri în 2019.

5. Majoritatea deceselor sunt înregistrate la pacienții cu ciroze hepatice la vârsta de 70-79 de ani.

6. Mai frecvent, hepatitele cronice se înregistrează la femei, iar cirozele hepatice și cancerul hepatic se evidențiază la bărbați.

7. Vârsta medie a pacienților cu hepatite cronice a constituit $57,74 \pm 11,22$, cu ciroze hepatice $56,21 \pm 10,17$ și cancer hepatic 59,05 $\pm 10,94$. 
8. Factorii de risc s-au dovedit a fi relații sexuale neprotejate, utilizarea obiectelor ascuțite în comun, utilizarea în comun a foarfecii și a seringilor, nerespectarea regimului alimentar și consumul de alcool și de tutun.

9. Peste $90 \%$ dintre pacienții cu hepatite cronice și cu ciroze hepatice s-au aflat în staţionar, pentru tratament, doar 10 zile.

10. Pacienții cu hepatite cronice au primit tratament antiviral doar în $24,68 \%$ de cazuri, iar cei cu ciroze hepatice -21,95\%.

11. Membrii familiilor au fost investigați la prezența markerilor virali doar în 38,81\% de cazuri, în hepatite cronice și 24,37\% - cu ciroze hepatice.

12. Vaccinarea membrilor familiei, împotriva hepatitei virale B, după depistarea bolnavului cu hepatită virală cronică B, au menționat 18,46\%, iar dintre cei cu ciroze hepatice - 15,25\%.

13. Pacienții cu hepatite cronice și ciroze hepatice au evidențiat prezența condițiilor nocive de muncă, cum ar fi lucru cu îngrășăminte, insecticide, pesticide, detergenți chimici, activități la ferma de animale etc.

\section{CONFLICT DE INTERESE}

Autorul declară că nu sunt conflicte de interese

\section{APROBAREA ETICĂ}

1. Paraschiv A. Studiu epidemiologic retrospectiv privind morbiditatea prin hepatite cronice și ciroze hepatice. Buletinul Academiei Sttiinţe a Moldovei. Stiinţe Medicale. 2017;2:201-5.

2. Paraschiv A., Secrieru C. Aspecte epidemiologice şi unii factori de risc în ciroze hepatice virale. Anale stiințifice USMF "Nicolae Testemițanu", Editia a XIII-a. 2012.

3. Dănuț-Laurențiu N. Patologia digestivă cronică abordare actuală și de perspectivă. 2017.

4. Feofanov IS, Mihailov D. Unele particularităţi ale procesului epidemic în hepatitele cronice şi cirozele hepatice nonvirale în municipiul Chişinău. Sănătate publică, Economie și Management în Medicină 2014;6(57):45-6.

5. Stanaway J.D., Flaxman A.D., Naghavi M., Fitzmaurice C., Vos T., Abubakar I., et al. The global burden of viral hepatitis from 1990 to 2013: findings from the Global Burden of Disease Study 2013. Lancet. 2016;388(10049):1081-8.

6. Pimpin L., Cortez-Pinto H., Negro F., Corbould E., Lazarus J. V., Webber L. et al. Burden of liver disease in Europe: Epidemiology and analysis of risk factors to identify prevention policies. Journal Hepatology. 2018. doi:10.1016/j.jhep.2018.05.011

7. Sepanlou S. G., Safiri S., Bisignano C., Ikuta K. S., Merat S., Saberifiroozi M. et al. The global, regional, and national burden of cirrhosis by cause in 195

Date of receipt of the manuscript: 07/02/2021

Date of acceptance for publication: 15/03/2021

Angela PARASCHIV, ORCID ID: 0000-0003-0817-8316
Studiul a fost aprobat prin aviz favorabil al Comitetului de Etică și Cercetare nr. 90 din 21.06.2017.

countries and territories, 1990-2017: a systematic analysis for the Global Burden of Disease Study 2017. Lancet Gastroenterol Hepatology. 2020;5(3):245-66.

8. Paula De Souza N., Melo Villar L., José A., Garbin Í., Adas T., Rovida S. et al. Assessment of health-related quality of life and related factors in patients with chronic liver disease. Brazilian Journal Infection Disease. 2015; 19:590-5. doi:10.1016/j.bjid. 2015.08.003

9. WHO. Global Health Sector strategy on Viral Heapatitis 2016-2021. WHO Guidlines. 2016.

10. Blachier M., Leleu H., Peck-Radosavljevic M., Valla D-C., Roudot-Thoraval F. The burden of liver disease in Europe: A review of available epidemiological data. Journal of Hepatology. 2013;58. Disponibil: http://data.euro.who.int [Accesat 23 septembrie 2019].

11. Waheed Y., Siddiq M., Jamil Z., Najmi M. H. Hepatitis elimination by 2030: Progress and challenges. World Journal of Gastroenterology. 2018;24:495961.

12. Mayevskaya M. V. Alkogol', alkogolizm i svyazannyye s nimi posledstviya. Rossiyskiy zhurnal gastroenterologii, gepatologii, koloproktologii [Alcohol, alcoholism and related consequences. Russian journal of gastroenterology, hepatology, coloproctology]. 2013;6:43-8. 